\title{
Cutaneous cystic lesions: its clinicopathological correlation with emphasis on unusual findings.
}

\author{
Inbasekaran P. ${ }^{1 *}$, Ramachandran T. ${ }^{2}$, Sivadharshini S.J. ${ }^{3}$, Murugan R. ${ }^{4}$ \\ DOI: https://doi.org/10.17511/jopm.2021.i03.07
}

\footnotetext{
1* Poovizhi Inbasekaran, Assistant Professor, Department of Pathology, Vinayaka Missions Kirupananda Variyar Medical College and Hospital, Salem, Tamil Nadu, India.

2 Thamilselvi Ramachandran, Professor and Head, Department of Pathology, Vinayaka Missions Kirupananda Variyar Medical College and Hospital, Salem, Tamil Nadu, India.

3 Sivadharshini S.J, Senior Resident, Department of Pathology, Vinayaka Missions Kirupananda Variyar Medical College and Hospital, Salem, Tamil Nadu, India.

4 Roopmala Murugan, Associate Professor, Department of Pathology, Vinayaka Missions Kirupananda Variyar Medical College and Hospital, Salem, Tamil Nadu, India.
}

Background: Cutaneous cysts are the most common lesions encountered in surgical practice with cosmetic and psychological concern to the patient. Aim: To establish the clinicopathological correlation of these lesions and also the importance of histological evaluation for the prevention of misdiagnosing a benign-appearing malignant lesion. Methods: A retrospective descriptive study with data collected from archives of histopathology from January 2018 to December 2020 of clinically diagnosed cutaneous cyst along with age, gender, location and histopathological evaluation were analysed. Results: 88 cases that were clinically diagnosed as cutaneous cysts had a higher female proportion $52.3 \%$. The most common clinical diagnosis is epidermal/ sebaceous cyst. $35.2 \%$ of cases were clinically diagnosed accurately but $64.8 \%$ of cases did not correlate with clinical diagnosis. 4 malignant lesions were misdiagnosed as benign cutaneous cyst clinically. Conclusion: Most often clinically diagnosed cutaneous cysts are not sent for histopathological evaluation which is a very important tool to confirm the diagnosis.

Keywords: Cutaneous cyst, Misdiagnosed, Malignant lesion

Corresponding Author

Poovizhi Inbasekaran, Assistant Professor, Department of Pathology, Vinayaka Missions Kirupananda Variyar Medical College and Hospital, Salem, Tamil Nadu, India.

Email: drpoovizhi24@gmail.com
How to Cite this Article

To Browse

Inbasekaran P, Ramachandran T, Sivadharshini SJ, Murugan R. Cutaneous cystic lesions: its clinicopathological correlation with emphasis on unusual findings.. Trop J Pathol Microbiol. $2021 ; 7(3): 135-143$.

Available From

https://pathology.medresearch.in/index.php/jopm/ar

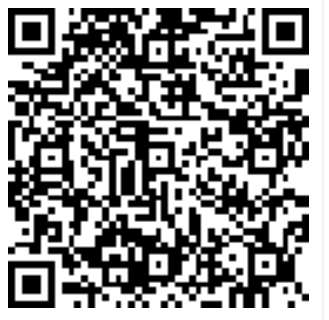
ticle/view/539

$\begin{array}{cc}\begin{array}{c}\text { Manuscript Received } \\ 2021-05-20\end{array} & \begin{array}{c}\text { Review Round } \mathbf{1} \\ 2021-05-30\end{array} \\ \begin{array}{c}\text { Conflict of Interest } \\ \text { No }\end{array} & \begin{array}{c}\text { Funding } \\ \text { Nil }\end{array}\end{array}$

Review Round 2
2021-06-10
Ethical Approval
Yes

(C) 2021 by Poovizhi Inbasekaran, Thamilselvi Ramachandran, Sivadharshini S.J, Roopmala Murugan and Published by Siddharth Health Research and Social Welfare Society. This is an Open Access article licensed under a Creative Commons Attribution 4.0 International License https://creativecommons.org/licenses/by/4.0/ unported [CC BY 4.0]. 


\section{Introduction}

A cyst is an enclosed space or an abnormal sac lined by epithelium containing fluid or semisolid substance within a tissue [1]. Cutaneous cysts are the most common benign lesions presenting as circumscribed dermal or subcutaneous lesions [2]. Most commonly these cysts are clinically diagnosed as sebaceous cysts which is a misnomer and should be regularly confirmed by histopathological examination. A sebaceous cyst is preferably described as either an epidermal inclusion cyst or trichilemmal (pilar) cyst $[3,4,5,6]$.

The most common cutaneous cyst is the epidermal inclusion cyst which is a retention cyst arising from skin appendages, trichilemmal cyst arises from a follicular isthmus of the external root sheath of the hair follicle [6]. Dermoid cysts are also developmental cyst which lacks any entry port and has a predilection for lines of embryonic fusion. Sweat gland elements may also produce cysts of apocrine or eccrine derivation classified as hidrocystomas [5]. These cysts evoke cosmetic or health problems that are of concern for both the patient and their clinicians where surgical removal is the mode of treatment when indicated.

Based on the histological features cutaneous cysts are classified as (i) cysts lined by stratified squamous epithelium, (ii) cysts lined by nonstratified squamous epithelium, and (iii) cysts without lining epithelium $[1,2]$. Correlation between clinical and histopathological diagnosis is very important for assessing the recurrence rate, infection and malignancy in the specimen which can help modify the treatment plan. This study evaluates cutaneous cysts based on age, gender, location, clinical diagnosis, clinicopathological correlation with emphasis on histopathological findings.

\section{Methods}

Setting: Department of pathology, Vinayaka Missions Kirupananda Variyar Medical College \& Hospital

Duration and type of study: A Retrospective descriptive study conducted for a period of 3 years from January 2018 to December 2020.

Sampling methods: All clinically diagnosed cutaneous cyst lesion samples received in the department of pathology.
Sample size: 88 cases

Inclusion criteria: All clinically diagnosed cutaneous cystic lesions received in the histopathology section.

Exclusion criteria: Cystic lesions arising from soft tissues and retroperitoneal region, brain and other solid organs.

Data collection procedure: Data of all clinically diagnosed cutaneous cystic lesions was retrieved from archives of the department of pathology from January 2018 to December 2020. Details were collected mainly based on age, gender, location, clinical diagnosis and histopathology report on routine Hematoxylin and Eosin stained slides

Statistical Analysis: The data were entered in a Microsoft Excel format. Descriptive analysis percentage (proportion) and mean (SD) were done for ordinal and continuous data respectively.

\section{Ethical consideration \& permission: Yes}

\section{Results}

A total of 88 cases clinically diagnosed as mucocutaneous cysts from January 2018 to December 2020 were included in the study. Age ranged from 8 months- 75 years with the mean age being $38.66 \pm 19.5$ years. The proportion of female 46 cases $(52.3 \%)$ was higher than male 42 cases $(47.7 \%)$. Patients were categorized into four groups based on their age, $\leq 15,16-30,31-60$, and $>60$ years where, most of the patients belonged to the 31-60years age group (Figure 1).

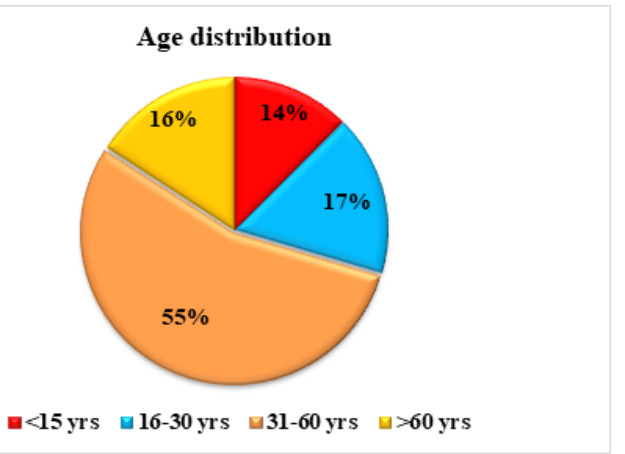

Figure 1: Age distribution of patients with the clinical diagnosis of cutaneous cyst

The most common clinically diagnosed cyst was epidermal cyst $42(47.7 \%)$ followed by dermoid cyst $17(19.3 \%)$, Mucosal cyst 05(5.7\%), cyst wall 13(14.8\%), vulvar cyst/ Bartholin's cyst 02(2.3\%), 
Cystic hygroma/ lymph cyst 03(3.4\%) and other types of cyst $05(5.5 \%)$ (Figure 2 ).

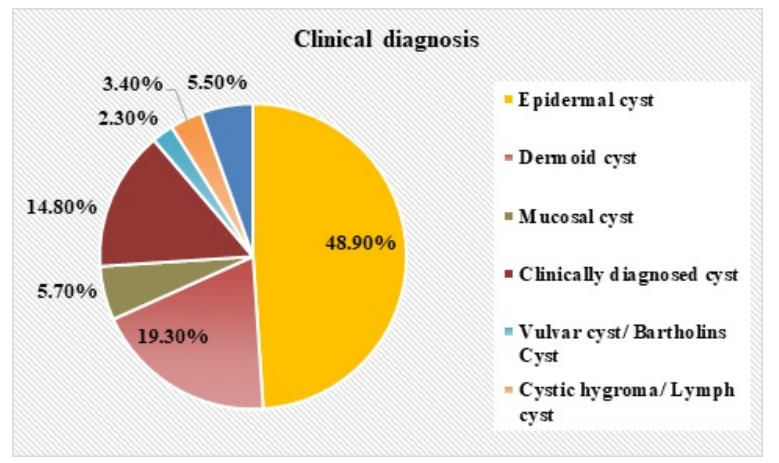

Figure 2: Distribution of cases based on clinical diagnosis of cutaneous cyst

Table 1 represents the epidemiological features of cutaneous cysts confirmed by histopathology.
Among 88 clinically diagnosed mucocutaneous cysts, two thirds $57(64.8 \%)$ were not compatible with the histopathological diagnosis. The upper limb was the most common site of involvement of the epidermal cyst. Among 43 reported cases, the majority $28(65.1 \%)$ them were young adults (31$60 y \mathrm{rs})$, in which $26(60.5 \%)$ were male and $17(39.55)$ were female. About $18(41.9 \%)$ cases were compatible with histopathology and $25(58.1 \%)$ cases failed, out of which $05(11.6 \%)$ cases were benign and $01(2.4 \%)$ case was malignant. $14(15.9 \%)$ cases showed epidermal cyst with giant cell reaction, $2(2.3 \%)$ cases showed trichilemmal cyst with giant cell reaction and $2(2.3 \%)$ cases showed dermoid cyst with giant cell reaction. Fungal abscess and the granulomatous reaction was seen in 1 case each. Calcinosis cutis was seen in $5(5.6 \%)$ cases.

Table 1: Epidemiological features of cutaneous cysts confirmed by histopathology

\begin{tabular}{|l|l|l|l|l|l|l|l|l|l|l|}
\hline \multirow{2}{*}{ Cutaneous cyst(clinical diagnosis) } & \multicolumn{2}{|c|}{ Sex } & \multicolumn{3}{|c|}{ Agea } & \multicolumn{2}{l|}{ Location of cysts } & \multicolumn{2}{l|}{ Conformityc N (\%) } & \multicolumn{2}{|c|}{ Neoplasm } \\
\cline { 2 - 12 } & Male $\mathrm{n}(\%)$ & Female $\mathrm{n}(\%)$ & Years & $\mathrm{n}(\%)$ & Location & $\mathrm{N}(\%)$ & Matched & Un matched & Benign & Malignant \\
\hline Epidermal cyst (43) & $26(60.5)$ & $17(39.5)$ & $31-60$ & $28(65.1)$ & UL & $10(23.3)$ & $18(41.9)$ & $25(58.1)$ & $05(11.6)$ & $01(2.4)$ \\
\hline Dermoid cyst (17) & $08(47.1)$ & $09(52.9)$ & $31-60$ & $08(47.8)$ & Face & $06(35.3)$ & $04(23.5)$ & $13(76.4)$ & $02(11.8)$ & $01(5.9)$ \\
\hline Mucosal cyst (05) & $01(20.0)$ & $04(80.0)$ & $31-60$ & $02(40.0)$ & Face & $04(80.0)$ & $02(40)$ & $03(60)$ & $01(20.0)$ & 0 \\
\hline Clinically diagnosed cyst (13) & $04(30.8)$ & $09(69.2)$ & $31-60$ & $07(53.8)$ & LL/S/UL & $02(15.4)$ & $01(7.6)$ & $12(92.4)$ & $01(7.7)$ & $01(20)$ \\
\hline Vulvar cyst/ Bartholins Cyst (02) & $0(0)$ & $02(100)$ & $<1516-30$ & $01(50.0) 01(50.0)$ & Vulva & $02(100)$ & $01(50.0)$ & $01(50.0)$ & 0 & 0 \\
\hline Cystic hygroma/ Lymph cyst (03) & $01(33.3)$ & $02(66.7)$ & $<15$ & $02(66.7)$ & Neck & $03(100)$ & $02(66.7)$ & $01(33.3)$ & 0 & 0 \\
\hline Infected branchial cyst (01) & $0(0)$ & $01(100)$ & $>60$ & $01(100)$ & Neck & $01(100)$ & 0 & $01(100)$ & 0 & $01(100)$ \\
\hline Thyroglossal cyst (01) & $01(100)$ & $0(0)$ & $31-60$ & $01(100)$ & Neck & $01(100)$ & $1(100)$ & $0(0)$ & 0 & 0 \\
\hline Ganglion & $01(100)$ & 0() & $>60$ & $01(100)$ & LL & $01(100)$ & 0 & $01(100)$ & 0 & 0 \\
\hline Cutaneous horn (01) & $0(0)$ & $1(100)$ & $31-60$ & $01(100)$ & Face & $01(100)$ & $01(100)$ & 0 & 0 & 0 \\
\hline Urachal cyst wall (01) & $0(0)$ & $1(100)$ & $31-60$ & $01(100)$ & Abdomen & $01(100)$ & $1(100)$ & $0(0)$ & 0 & 0 \\
\hline
\end{tabular}

AThe most prevalent age group, bThe most common location of the cyst, cConfirmity of clinical diagnosis with histopathology.

About $13(14.7 \%)$ cases were reported to have a misdiagnosis of neoplastic lesion. Most of the misdiagnosed cysts were epidermal 06(46.1\%), dermoid 03(23.07\%), mucosal01(7.6\%), cyst wall $02(15.4 \%)$ and infected brachial cyst $01(7.6 \%)$.
The misdiagnosed neoplastic lesions were pigmented pilomatricoma with sebaceous cyst $(n=1), \quad$ myopericytoma $(n=1), \quad$ eccrine hidradenoma $(n=1)$, chondroid syringom $(n=1)$, palisaded \& encapsulated neuroma $(n=1)$, malignant eccrine poroma $(n=1)$, fibroma $(n=1)$, lipoma $(n=2)$, metastatic papillary carcinoma $(n=1)$, plexiform neurofibroma $(n=1)$, carcinoma with medullary features $(n=1)$ and papillary carcinoma thyroid with cystic degeneration $(n=1)$ (Table 2 ).

Table 2: Clinical diagnosis distribution of 13 misdiagnosed neoplastic lesions

\begin{tabular}{|l|l|l|l|l|l|l|}
\hline \multirow{2}{*}{ Neoplastic lesions } & \multicolumn{5}{c|}{ Misdiagnosed clinical cases N=13 (14.7\%) } & Total \\
\cline { 2 - 8 } & Epidermal cyst & Dermoid cyst & Mucosal cyst & Clinically diagnosed cyst & Infected branchial cyst & \\
\hline Pigmented pilomatricoma with sebaceous cyst & 1 & 0 & 0 & 0 & 0 & 1 \\
\hline Myopericytoma & 1 & 0 & 0 & 0 & 0 & 1 \\
\hline
\end{tabular}


Inbasekaran P. et al: Cutaneous cystic lesions: its clinicopathological

\begin{tabular}{|l|l|l|l|l|l|}
\hline Eccrine hidradenoma & 1 & 0 & 0 & 0 \\
\hline Chondroid syringoma & 1 & 0 & 0 & 0 & 0 \\
\hline Palisaded \& encapsulated neuroma & 1 & 0 & 0 & 0 & 1 \\
\hline Malignant eccrine poroma & 1 & 0 & 0 & 0 & 0 \\
\hline Fibroma & 0 & 1 & 0 & 0 & 0 \\
\hline Lipoma & 0 & 1 & 0 & 1 & 1 \\
\hline Metastatic papillary carcinoma & 0 & 0 & 0 & 0 \\
\hline Plexiform neurofibroma & 0 & 0 & 1 & 0 & 1 \\
\hline Carcinoma with medullary features & 0 & 0 & 0 & 1 & 0 \\
\hline Papillary carcinoma thyroid with cystic degeneration & 0 & 0 & 0 & 0 & 1 \\
\hline Total neoplastic lesions & $06(46.1 \%)$ & $03(23.07 \%)$ & $01(7.6 \%)$ & $02(15.4 \%)$ & $01(7.6 \%)$ \\
\hline
\end{tabular}

\section{Discussion}

In our study epidermal cyst (48.90\%) followed by dermoid cyst (19.30\%) was the most common clinical diagnosis which was similar to the study conducted by Al-Khateeb et al and Kamyab et al $[3,4,5]$. The cases with the clinical diagnosis of trichelimmal cyst were mostly diagnosed histopathologically as epidermal and dermoid cyst [6]. 40 (45.4\%)cases were diagnosed as epidermoid cyst, of which $14(15.9 \%)$ cases showed giant cell reaction (Figure 3.a,b) which was highlighted in a study by Nijam et al where $10(9 \%)$ cases had giant cell reaction in epidermoid cyst probably due to rupture. Epidermoid cyst of the breast can mimic benign or malignant breast lesions clinically and radiologically. Very few cases have been reported in the literature, which can occur in the breast parenchyma and the skin layer. In our study one such case of the epidermoid cyst from the skin layer of the left breast was found $[7,8]$. One clinically diagnosed ganglion cyst was histopathologically diagnosed as the epidermoid cyst.

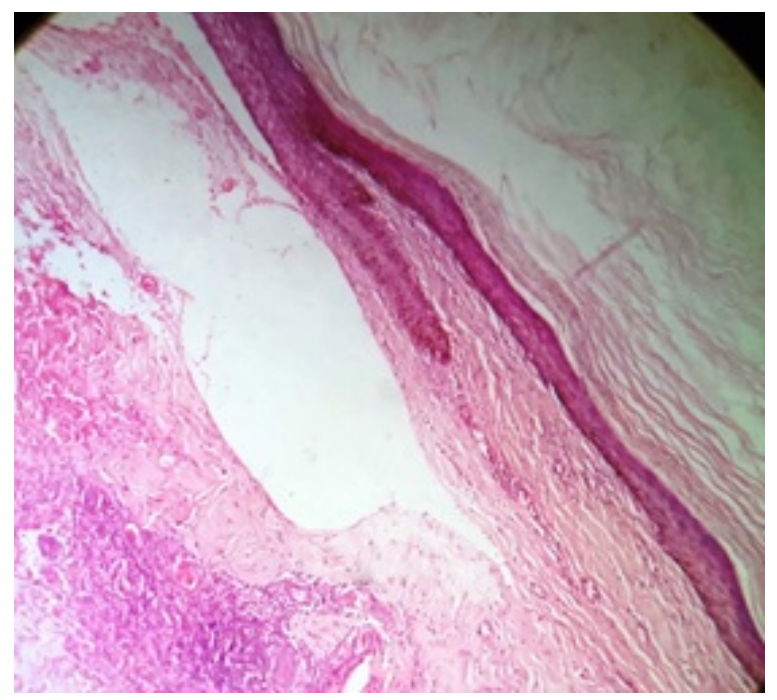

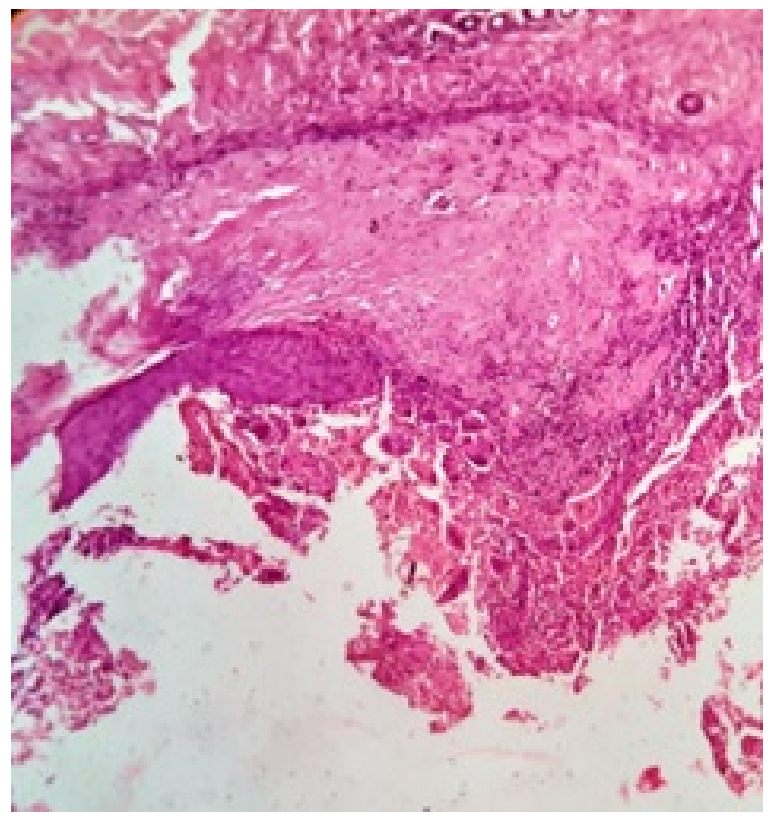

\section{Figure 3: A. Epidermoid cyst, b.Giant cell reaction ( $H \& E$ 10x)}

Trichilemmal cysts lined by stratified squamous epithelium without granular layer was found in 6 $(6.8 \%)$ case of which $2(2.3 \%)$ case showed giant cell reaction due to rupture [6]

The dermoid cyst was seen in $6(6.8 \%)$ cases which were also clinically diagnosed the same of which two cases showed giant cell reaction. In our study, the face was the common site similar to other studies $[3,4]$. Cystic hygroma or lymphangioma is a benign congenital malformation of the lymphatic system which is most commonly seen in children and rare in adults. In the present study $4(4.5 \%)$ cases of lymphangioma, out of which 2 cases were seen in children and 2 cases was seen in adults which is rare $[9,10]$. The most common location is the neck region which is similar in our study [10]. 
Calcinosis cutis is an accumulation or deposition of calcium salts in the skin and subcutaneous tissue [11]. After diagnosing calcinosis cutis, laboratory workup to rule out calcium and phosphorus metabolism, excess vitamin D intake, renal insufficiency, malignancy should be done to identify the underlying cause of the disease $[11,12]$. In our study $5.6 \%$ of cases showed calcinosis cutis and all were clinically diagnosed as sebaceous cyst where inflammation and rupture of epidermoid cyst is the most probable pathogenic mechanism $[12,13]$.

One case clinically diagnosed as a sebaceous cyst without any suspicion of infection was histopathologically diagnosed as a fungal abscess with giant cell reaction, where even after surgical excision, the antifungal drug is the main mode of treatment. Fibroma clinically misdiagnosed as the dermoid cyst was seen in the right index finger also known as cutaneous digital fibroma is a benign fibrous lesion in the dermis $[14,15]$. Histologically they show proliferation of fibroblast that is uniformly slender with a minimal myxoid component in the dermis which was similar in our study [14].

Eccrine hidradenoma is a benign tumour of the sweat gland which can be either solid or cystic. Histologically they are well-circumscribed lesions composed of solid and cystic areas, solid area shows polyhedral cells with basophilic cytoplasm or round cells with clear cytoplasm $[16,17,18]$. Wide surgical excision is the mode of treatment to minimize the recurrence of tumors even though malignant transformation is rare [16]. In our study dual lesion of eccrine hidradenoma with cystic change and the epidermoid cyst was seen (Figure 4).

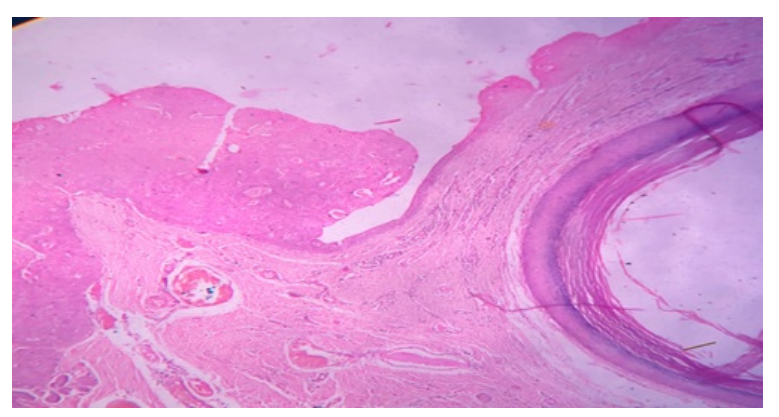

Figure 4: Eccrine hidradenoma, Cystic and solid area with epidermoid cyst (H\&E 10x)

Chondroid syringoma is a rare, mixed tumor of the sweat gland described by Billroth, which reveals differentiation towards the adnexal ductal epithelium with chondromyxoid differentiation in the stroma.
A similar finding was seen in one case which was misdiagnosed clinically sebaceous cyst in our study $[19,20]$. Though malignant component is also reported in literature only histopathology can help in differentiating it from benign lesion [19].

Cutaneous myopericytoma is an uncommon benign neoplasm that is characterised by wellcircumscribed, unencapsulated lesion with the nodular proliferation of thin-walled vessels showing the concentric perivascular arrangement of ovoid spindle-shaped myopericytes in the dermis, subcutis or soft tissue $[20,21]$. In our study one case was seen which was clinically diagnosed as epidermoid cyst similar to a study by Anug et al which also showed one of the cases diagnosed as a cystic lesion (Figure 5).

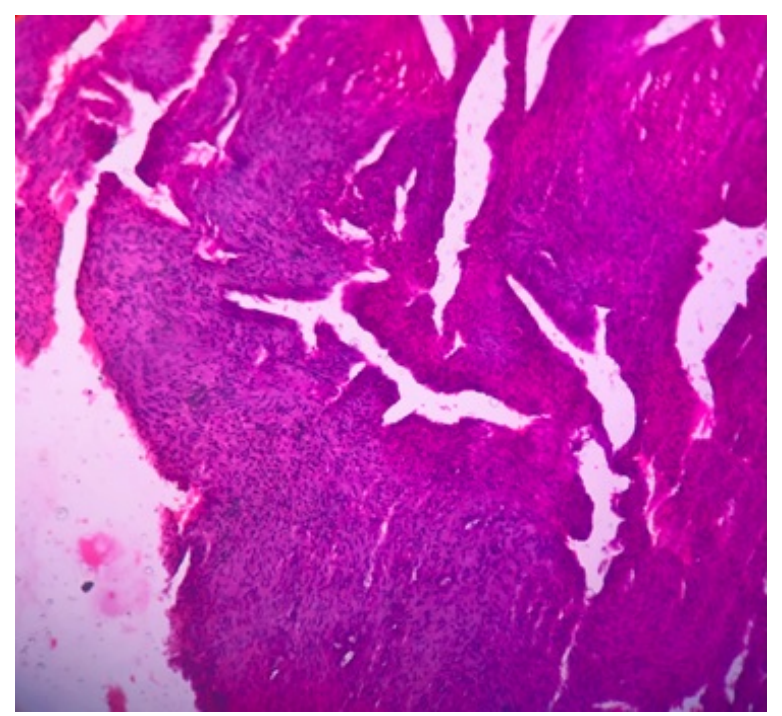

Figure 5: Cutaneous myopericytoma (H\&E 10x)

Palisaded encapsulated neuroma is a benign neural tumor in the skin first described by Reed et al [22]. Histologically they are well-circumscribed encapsulated tumor composed of wavy spindle cells arranged in a palisading pattern $[22,23]$. In our study it was seen in a (60years) elderly patient but it is most common in middle-aged adults as per Batra et al. Pigmented pilomatricoma is a variant of pilomatricoma a very rare entity with wellcircumscribed nodular lesion characterised by aggregates of basaloid cells, centrally filled with ghost cells, presence of melanin pigment within the cytoplasm of basiloid cells and ghost cells which was seen in our study too $[24,25]$. A dual lesion with the presence of pigmented pilomatricoma with epidermoid cyst was seen in our study (Figure 6.a,b). 

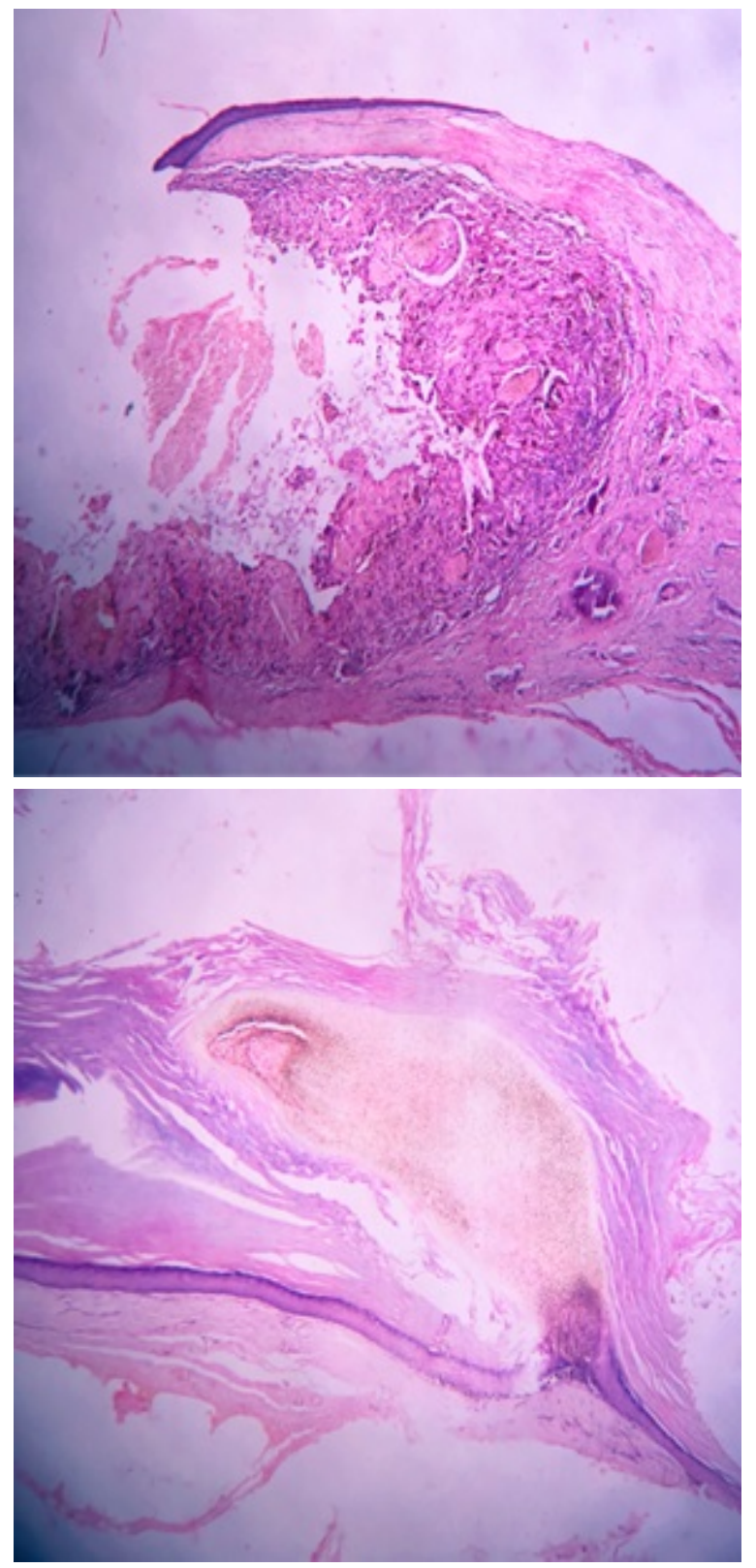

Figure 6: Pigmented pilomatricoma, a. Basiloid cells with melanin pigment, $b$. Ghost cells with melanin pigment and epidermoid cyst ( H\&E 10x)

Plexiform neurofibroma is benign tumors of nerve sheath origin that can present as a solitary origin or as part of von Recklinghausen's disease. Histologically they show a mixture of Schwann cells, perineurial cells and endoneurial fibroblasts, which are unencapsulated $[25,26,27]$. In our study one case which was misdiagnosed clinically as a mucosal cyst in the upper lip was seen in a 34-year female as a solitary lesion [26].
$8(10.4 \%)$ cases were benign neoplastic lesions that were misdiagnosed clinically, of which one was a fungal infection that required antifungal treatment. Few benign lesions have a high recurrence rate where they might need wide local excision and few may require regular follow-up, whereby all these can be diagnosed and could help the clinicians treat the patients appropriately $[3,4]$. Out of $13(14.7 \%)$ clinically misdiagnosed neoplastic lesions $4(4.4 \%)$ were malignant histopathologically, of which one was malignant eccrine poroma clinically diagnosed as an epidermoid cyst in the forehead. Malignant eccrine poroma or eccrine porocarcinoma is a rare adnexal tumour arising from eccrine sweat glands. It was first described by Pinkus and Mehregan in 1963 and accounts for $0.005 \%$ to $0.01 \%$ of all cutaneous tumors $[28,29,30]$. The most common age group is the 7th and 8th decade which was similar in our study [28]. Histopathology revealed irregular cord and lobules of polygonal basaloid tumor cells which proliferate asymmetrically with cytological and nuclear pleomorphism, mitosis is seen in the dermis and often invading into subcutaneous tissue is common as seen in our present study (Figure 7). They have a poor prognosis, as local recurrence and metastasis is common $[28,31]$. 3cases were metastatic lesions of which 2 were papillary carcinoma (Figure 8 ) of which one was clinically diagnosed as dermoid cyst and the other as cyst wall. 3rd case was histopathologically diagnosed as carcinoma with medullary features which was clinically diagnosed as a thick-walled cyst.

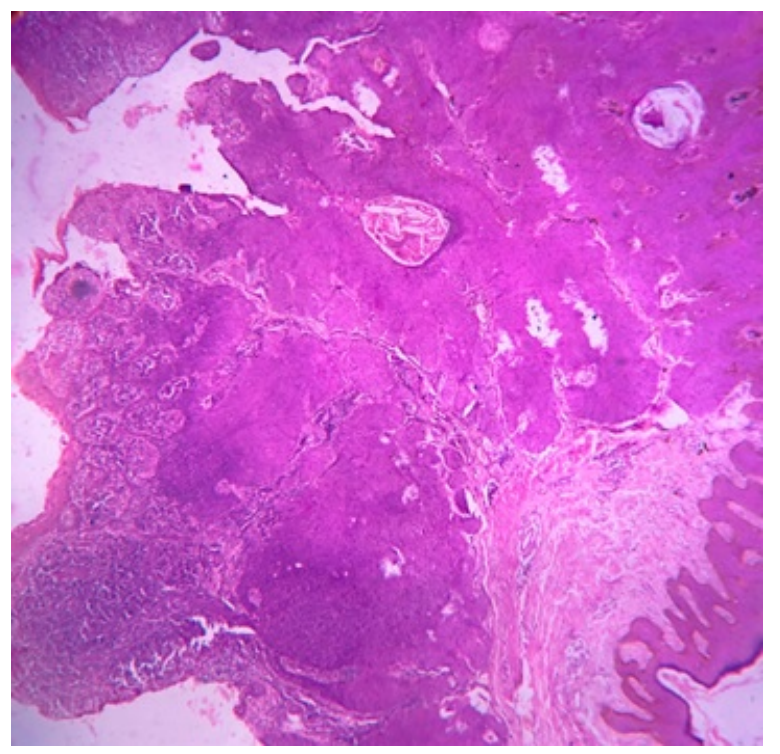

Figure 7: Malignant eccrine poroma (H\&E 10x) 


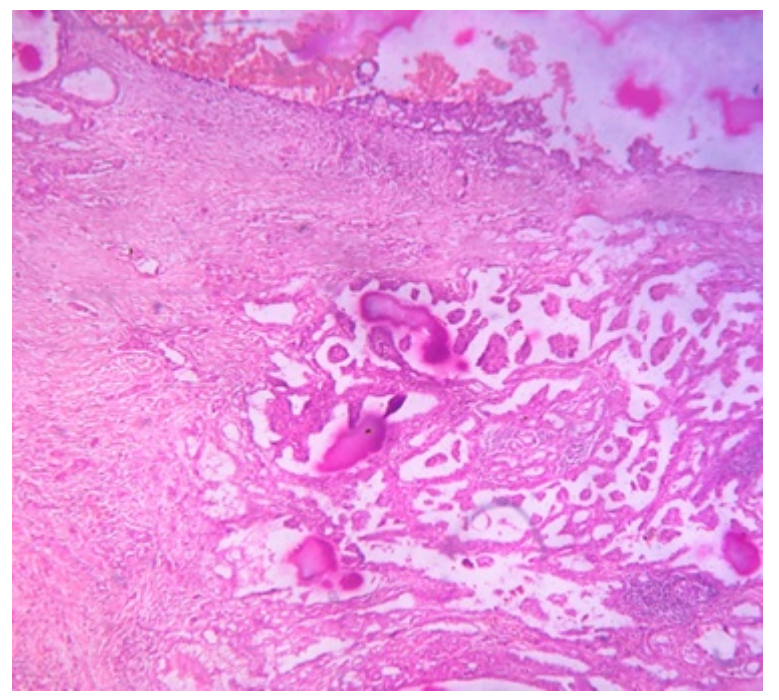

Figure 8: Metastatic papillary carcinoma (H\&E 10x)

The study by Apollos et al suggests that with proper preoperative clinical examination and diagnosis every cyst need not be sent for pathological examination. However Apollos et al suggest the contents of the cyst should be examined postoperatively for the presence of a solid area or any high suspicion should be sent for histopathologic examination [32]. Histopathology is the main modality in the diagnosis of the above cases without any clinical suspicion of malignancy. Although the possibility of misdiagnosing a malignant lesion as a cystic lesion is very low it has a huge impact on treatment $[3,4,7,32]$.

\section{Conclusion}

Most of the cutaneous cysts are correctly diagnosed clinically but there are quite a several cases that are misdiagnosed, as some of the malignant lesions might appear clinically benign, its sequela is huge and irreparable to the patients. Histopathology plays the main role in diagnosing such cases where it highly helps clinicians to decide the treatment plan for the patient.

\section{What new this study adds to existing knowledge?}

It is imperative that every cutaneous cyst excised should undergo histomorphological examination although the clinical diagnosis may be an innocuous-sounding sebaceous cyst, as clinical investigation alone sometimes might miss malignant lesions mimicking the appearance of benign lesions.

\section{Author contribution}

Dr. Poovizhi Inbasekaran: data collection, data compiling, literature review, manuscript preparation, manuscript editing.

Dr. Thamilselvi R: manuscript editing, final approval

Dr. Sivadharshini S.J: data collection, manuscript editing

Dr. Roopmala M: manuscript editing

\section{Reference}

01. Johnston RB. 16 - cysts, sinuses, and pits, InJohnston RB, ed, Weedon's Skin Pathology Essentials, 2nd edn. Amsterdam, the NetherlandsElsevier. 2017;329-348. [Crossref][PubMed][Google Scholar]

02. Taylor R S, Perone J B, Kaddu S, Kerl H. Appendage tumors and hamartomas of the skin, Fitzpatrick's dermatology in general medicine. 7th ed, New York- McGraw-Hill. 2008;1068-1087. [Crossref][PubMed][Google Scholar]

03. Kamyab K, Kianfar N, Dasdar S, Salehpour Z, Nasimi M. Cutaneous cysts- a clinicopathologic analysis of 2,438 cases. Int J Dermatol. 2020 Apr;59(4)457-462. doi: 10.1111/ijd.14808 [Crossref][PubMed][Google Scholar]

04. Al-Khateeb TH, Al-Masri NM, Al-Zoubi F. Cutaneous cysts of the head and neck. J Oral Maxillofac Surg. 2009 Jan;67(1)52-7. doi: 10.1016/j.joms.2007.05.023 [Crossref][PubMed] [Google Scholar]

05. Golden BA, Zide MF. Cutaneous cysts of the head and neck. J Oral Maxillofac Surg. 2005 Nov;63(11)1613-9. doi: 10.1016/j.joms.2005.08. 002 [Crossref][PubMed][Google Scholar]

06. Ramaswamy AS, Manjunatha HK, Sunilkumar B, Arunkumar SP. Morphological spectrum of pilar cysts. N Am J Med Sci. 2013 Feb;5(2)124-8. doi: 10.4103/1947-2714.107532 [Crossref][PubMed] [Google Scholar]

07. Nigam JS, Bharti JN, Nair V, Gargade CB, Deshpande AH, Dey B, Singh A. Epidermal Cysts- A Clinicopathological Analysis with Emphasis on Unusual Findings. Int J Trichology. 2017 JulSep;9(3)108-112. doi: 10.4103/ijt.ijt_16_17 [Crossref][PubMed][Google Scholar] 
08. Phukan JP, Sinha A, Pal S, Sinha R. Cytological diagnosis of epidermal inclusion cyst of breast- $A$ rare benign lesion. J Nat Sci Biol Med. 2014 Jul;5(2)460-2. doi: 10.4103/0976-9668.136251 [Crossref][PubMed][Google Scholar]

09. Derin S, Şahan M, Dere Y, Çullu N, Şahan L. Cervical cystic hygroma in an adult. Case Rep Pathol. 2014;209427. doi: 10.1155/2014/209427 [Crossref][PubMed][Google Scholar]

10. Mirza B, Ijaz L, Saleem M, Sharif M, Sheikh A. Cystic hygroma- an overview. J Cutan Aesthet Surg. 2010 Sep;3(3)39-44. doi: 10.4103/09742077. 74488 [Crossref][PubMed][Google Scholar]

11. James WD, Berger TG, Elston DM. Andrews' Diseases of the Skin: Clinical Dermatology. 11th ed. Philadelphia (PA)- Elsevier/Saunders. 2011;516-8 [Crossref][PubMed][Google Scholar]

12. Dubey S, Sharma R, Maheshwari V. Scrotal calcinosis- idiopathic or dystrophic?. Dermatol Online J. 2010 Feb 15;16(2)5. [Crossref][PubMed] [Google Scholar]

13. Bhat D, Parate S, Bobhate S K. Scrotal calcinosis presenting as nodular masses- A report of 4 cases. Ind J Dermat. 2003;48(2)112. [Crossref][PubMed] [Google Scholar]

14. Cohen PR, Alpert RS, Calame A. Cellular Digital Fibroma- A Comprehensive Review of a CD34Positive Acral Lesion of the Distal Fingers and Toes. Dermatol Ther (Heidelb). 2020 Oct;10(5)949-966. doi: $\quad 10.1007 / s 13555-020-00418-3$ [Crossref] [PubMed][Google Scholar]

15. Tardío, Juan C. "Dermal fibroma with a distinctive perivascular cell arrangement". The American Journal of Dermatopathology. 2008;30(6) 638-640. [Crossref][PubMed][Google Scholar]

16. Kataria S P, Singh G, Batra A, Kumar S, Kumar $V$, Singh $P$. Nodular hidradenoma- a series of five cases in male subjects and review of literature. Adv Cytol Pathol. 2018;3(2)46-47. [Crossref][PubMed] [Google Scholar]

17. Li, Zi-Yuan, and Jian-Min Chang. "Solid-Cystic Hidradenoma". International Journal of Dermatology and Venereology. 2019;2(3)191-192. [Crossref] [PubMed][Google Scholar]

18. Paranjyothi M, Mukunda A. Clear cell hidradeno ma- An unusual tumor of the oral cavity. J Oral Maxi Ilofac Pathol. 2013;17(1)136-8. doi: 10.4103/097 3-029X.110719[Crossref][PubMed][Google Scholar]
19. Shilpa K, Leelavathy B, Divya G, Lakshmi D V. Chondroid syringoma- Histopathology a cornerstone tool in diagnosis. Indian J Dermatopathol Diagn Dermatol. 2016;3;20-1. doi:10.4103/23496029.184005 [Crossref][PubMed][Google Scholar]

20. Reddy PB, Nandini DB, Sreedevi R, Deepak BS. Benign chondroid syringoma affecting the upper lipReport of a rare case and review of literature. J Oral Maxillofac Pathol. 2018 Sep-Dec;2-2(3)401-405. doi: 10.4103/jomfp.JOMFP_35_18 [Crossref] [PubMed][Google Scholar]

21. Aung PP, Goldberg LJ, Mahalingam M, Bhawan J. Cutaneous Myopericytoma- A Report of 3 Cases and Review of the Literature. Dermatopathology (Basel). 2015 Feb 11;2(1)9-14. doi: 10.1159/000371875 [Crossref][PubMed][Google Scholar]

22. Batra J, Ramesh V, Molpariya A, Maan KK. Palisaded Encapsulated Neuroma- An Unusual Presentation. Indian Dermatol Online J. 2018 JulAug;9(4)262-264. doi: 10.4103/idoj.IDOJ_354_17 [Crossref][PubMed][Google Scholar]

23. Manchanda, Adesh S., Ramandeep Singh Narang, and Geetika Puri, "Palisaded encapsulated neuroma. " Journal of Orofacial Sciences. 2015;7(2)136. [Crossref][PubMed][Google Scholar]

24. Ishida $M$, Okabe $H$. Pigmented pilomatricomaan underrecognized variant. Int J Clin Exp Pathol. 2013 Aug 15;6(9)1890-3. [Crossref][PubMed] [Google Scholar]

25. Hernández-Núñez $A$, Nájera Botello $L$, Romero Maté $A$, Martínez-Sánchez $C$, Utrera Busquets $M$, Calderón Komáromy $A$, et al. Retrospective study of pilomatricoma- 261 tumors in 239 patients. Actas Dermosifiliogr. 2014 Sep;105(7)699-705. doi: 10.1016/j.ad.2014.01.003 [Crossref][PubMed] [Google Scholar]

26. Mahalle A, Gs Reddy M, Mohit Kheur S, Bagul N, Ingle $Y$. Solitary Non Syndromic Oral Plexiform Neurofibroma- a Case Report and Review of Literature. J Dent (Shiraz). 2016 Sep;17(3 Suppl)293-296. [Crossref][PubMed][Google Scholar]

27. Khetrapal S, Jairajpuri Z, Rana S, Pujani M, Jetley S. Plexiform Neurofibroma- An Unusual Diagnosis of Lip Swellings. IJSS Case Reports \& Reviews. 2015;1(12)1-3. [Crossref][PubMed] [Google Scholar] 
28. Salih AM, Kakamad FH, Essa RA, Rauf GM, S A $M, H M S$, et al. Porocarcinoma- A systematic review of literature with a single case report. Int J Surg Case Rep. 2017;30;13-16. doi: 10.1016/j.ijscr.2016.10.051 [Crossref][PubMed] [Google Scholar]

29. Kurashige $Y$, Minemura T, Nagatani T. Eccrine porocarcinoma- clinical and pathological report of eight cases. Case Rep Dermatol. 2013 Oct 4;5(3)259-66. doi: 10.1159/000355606 [Crossref] [PubMed][Google Scholar]

30. Luz Mde A, Ogata DC, Montenegro MF, Biasi LJ, Ribeiro LC. Eccrine porocarcinoma (malignant eccrine poroma)- a series of eight challenging cases. Clinics (Sao Paulo). 2010 Jul;65(7)739-42. doi: $\quad 10.1590 / S 1807-59322010000700014$ [Crossref][PubMed][Google Scholar]
31. Masamatti SS, Narasimha A, Bhat A, Chowdappa V. Eccrine Porocarcinoma of the ScalpA Rare Case Report with Review of Literature. J Clin Diagn Res. 2016 Jan;10(1)ED15-6. doi: 10.7860/JCDR/2016/16083.7149 [Crossref] [PubMed][Google Scholar]

32. Apollos JR, Ekatah GE, Ng GS, McFadyen AK, Whitelaw SC. Routine histological examination of epidermoid cysts to send or not to send?. Ann Med Surg (Lond). 2016 Dec 19;13;24-28. doi: 10.1016/j.amsu.2016.12.047 [Crossref][PubMed] [Google Scholar] 